\title{
Factors that Determines the Success of Corporate Sustainability Management
}

\author{
Hartono Rahardjo (Corresponding author) \\ Faculty of Business, Widya Mandala Catholic University \\ Jl. Dinoyo 42-44, Surabaya, 60265, Indonesia \\ Tel: 62-31-567-8478Ｅ-mail: hartono@pentatrust.com
}

\author{
M. S. Idrus, Djumilah Hadiwidjojo \& Siti Aisjah \\ Faculty of Economics and Business, University of Brawijaya, Indonesia \\ Jl. M.T.Haryono 165, Malang, 65145, Indonesia
}

Tel: 62-341-551396

Received: January 3, 2012 Accepted: January 14, 2013 Published: April 1, 2013

doi:10.5296/jmr.v5i2.2993 URL: http://dx.doi.org/10.5296/jmr.v5i2.2993

\begin{abstract}
The practice of Corporate Sustainability Management (CSM) is to believed strongly associated with management attitudes about the relationship of corporate sustainability management and corporate social responsibility. This literature review provides comprehensive indications that the CSM is an important management issue, complex and global nature. It is not apart from the company's position as a business institution that is able to influence and influenced by social conditions and environmental and position of management dilemma in meeting its profit and social responsibilities. CSM states that to survive in the long term, the management should have a balance between financial, social and environmental performance. The paradox attitude indicates economic interests are still the main reference in determining attitudes and policies of CSM. This article explores factors that determines the success of CSR program, which is corporate sustainability management. Using literature reviews, this article presents that at least there are five factors that should be met as a successful condition for the practice of CSM, namely: (1) the amount of commitments of shareholder to encourage the management engaged in solving social and environment issues, (2) the strength of humanist paradigm adopted by the management, (3) the ability of management achieves higher level sustainability performance, (4) the ability of management builds and run a strong sustainability culture that reflects the
\end{abstract}




\section{Macrothink}

Journal of Management Research ISSN 1941-899X 2013, Vol. 5, No. 2

principles of sustainability properly and (5) the ability of management builds mutually beneficial collaboration with the economic stakeholders.

Keywords: Corporate Sustainability Management, Profit responsibility, Social responsibility and economic stakeholders 


\section{Introduction}

Corporate Sustainability Management (CSM) is an important issue for the management today. In general, CSM is a management concept that states that the viability of the company is highly dependent on the ability to create optimal profit without causing environmental damage and social problems in the community (Ameer \& Othman, 2012). In its development, CSM is strongly associated with the concept of Corporate Social Responsibility, Corporate Social Responsiveness, Corporate Citizenship, business ethics, Triple Bottom Line Concept and debate of the relevance of economism and humanism paradigm adopted by the management (Pirson \& Lawrence, 2010). A company is a business institution that oriented to the profit therefore CSM becomes an important issue because it is related to the corporate profit responsibility as the main management responsibility.

The various surveys and research findings indicate that CSM is a concept that is easily understood, but it is difficult to implement (Ameer \& Othman, 2012; Kiron et al., 2012; Robinson \& Boulle, 2012). From a management perspective, it is generally agreed that social and environmental issues are important issues and can affect the survival of the company, but the management does not give enough attention to these issues. Other studies have also shown that although the management has implemented the CSM, it will not always improve the financial performance of the company (Kiron et al., 2012). Thus, there are still many questions to be answered to arrive at a belief that running the CSM is according to the demands of corporate profit responsibility.

The diversity research results on the relationship of CSM with the company's financial performance raises more fundamental questions: (1) why a company succeeds or fails in applying CSM? (2) What internal and external factors must be met as successful requirement of CSM practice? The answers to these questions are very important to strengthen the argument that CSM is an ideal concept. This article discusses the various sources to answer these questions with the aim of generating new propositions for further research.

\section{Literature Review}

\subsection{Corporate Sustainability Management (CSM) and Corporate Social Responsibility (CSR)}

CSM concept is understood as awareness of the interdependence between the company, the community and the environmental. This concept is increasingly believed the truth due to the more frequent global economic crisis caused business attitudes that not paying attention to the ethics, the balance of economic motivation, the protection of the interests of society and the environment quality. The company is a member of the public community that has the public rights. The company has the ability to influence and influenced by society and the environmental therefore it is not possible to separate the company with community and environmental. In its development, the CSM directly related with corporate profit responsibility (Kiron et al., 2012; Staton, 2011; Laszlo \& Zhexembayeva, 2011; Raynor, 2009). A company is required to sustain the survival while still showing the commitment to the economic prosperity of the community and demonstrating integrity to maintain the quality of the environmental, social justice and responsibility to mankind today and in the future. The concept of CSM places the company is part of the public that has the right and responsibility to maintain the public rights. 
In the context of the management of the company, CSM is strongly associated with the concept of Corporate Social Responsibility (CSR). CSR is a company's commitment to responsible for any negative effects caused by the operation of the company (Carroll, 1991; Jones et al., 2009). The responsibility is intended for the economic stakeholders and the social stakeholders. CSR has four dimensions, namely, economic, legal, ethical, and philanthropic, but in its development, CSR is often only understood partially only confined to community development and environmental protection activities (philanthropic activities). Thus, CSR is a consequence of a company when running the CSM concept.

\subsection{Result of Empirical Research of CSM}

The concept of CSM on the basic is how to maintain the viability of the company with responsibility for creating a balance of income and corporate social responsibility. This concept is a concept, which is logically easy to understand but difficult to practice. This is the conclusion of various research results.

CSM idealism states that the company that can implement the CSM will be able to protect the long-term financial performance. Nevertheless, Peters and Mullen (2009) identify that various studies on the relationship of CSM and corporate financial performance show various results (See table 1). Results of various research show that not all companies that carry out social responsibility to the society and environmental have better financial performance. Survey shows that the management recognizes that the public and the environment have the ability to affect the financial performance and company's sustainability, however the management does not put the public and the environmental as the most important stakeholders (Verschoor, 2008). The research of Jamali (2008) and Papasolomou et al., (2005) put the public and the environmental at the lowest order. These facts indicate that the management has paradoxical attitude in performing the social responsibilities towards the community and environmental.

Table 1. Various Research Results on The Relationship of Corporate Sustainability Management (CSM) and Corporate Financial Performance (CFP)

\begin{tabular}{|l|l|}
\hline Results & Author(s) \\
\hline $\begin{array}{l}\text { CSM activities enhance the corporate financial } \\
\text { performance }\end{array}$ & $\begin{array}{l}\text { Rahim et al., 2011; Clemens \& Bakstran, 2010; } \\
\text { Menguc et al.,2010; Falck \& Heblich, 2007; Verschoor, } \\
\text { 2003) }\end{array}$ \\
\hline $\begin{array}{l}\text { CSM activities do not influence the corporate financial } \\
\text { performance because CSM does not contribute stronger } \\
\text { competitive advantage position for management. }\end{array}$ & $\begin{array}{l}\text { Lanoizelee, 2011; Lee et al., 2009; Mittal et al., 2008; } \\
\text { Carter, 2005) }\end{array}$ \\
\hline $\begin{array}{l}\text { CSM activities only enhance a part of financial } \\
\text { performances. }\end{array}$ & $\begin{array}{l}\text { Cordasco, 2012; Gupta, 2012; Osthus, 2011; Andersen } \\
\text { \& Larsen, 2009; Laan et al., 2008; Maloni \& Brown, } \\
\text { 2006) }\end{array}$ \\
\hline
\end{tabular}

There are differences in perception between the company and the public expectations towards the environmental issues, human rights, empowerment of community, stability of economy and 
the gap between the rich and the poor. The society expects the company gives greater role but the management looks at solving such issues are not the primary responsibility of management (Verschoor, 2008). Perceptions of top management state that social and environmental issues are important issues, but addressing the problems is not the prime motivation for the management because these issues are not clear (Robins, 2008; Crook, 2005). Management has no credibility and a strong commitment to the social issues and the environmental because the demand to give more attention on these issues do not show the reality that confronted by the management everyday (Gioia, 1999). Not all companies are able to run profit sustainability in balance with environmental and social sustainability. The research of Ameer and Othman (2012) shows that companies that consistently apply the CSM will produce better long-term financial performance. Despite this research is limited only to large corporations on a global scale and show the different results from one country to another. Furthermore, Kiron et al., (2012) states that not all companies are able to enjoy better financial performance and success of the CSM, such as better collaboration with stakeholders and mutual cooperation with society.

\section{Discussion}

The diversity of the research results and the differences between the beliefs and attitudes of management raise questions of why a company successfully implements CSM and why other companies do not reap good financial performance despite applying CSM? Those questions raise five factors that should be noticed in order to apply CSM succesfully: (1) the principal-agent relationship, (2) the humanism paradigm adopted by the management, (3) the corporate culture, (4) the management ability to establish good relationship with all stakeholders, and (5) the internal conditions that in accordance with the the demands of the implementation of the concept of CSM. The following sections try to address some of these questions based on the review of existing literature.

\subsection{Attitude of Shareholders On Social and Environmental Issues.}

From the view of agency theory, the management committed to a principal agent relationship where the management is the agent of the shareholders (principal). Legally, the management is ressponsible to the shareholders because the shareholders are the owners of capital. The continuity of shareholder wealth depends on the ability of management generates maximum profits for the interest of shareholders. The company is an artificial person and only as a means to achieve the management goals. The only social responsibility is to create maximum profit in accordance with the ethics and applicable laws (Kolstad, 2007). This condition causes the management to be able to guarantee the survival of the company (corporate sustainability) with respect to various constraints of operations, including the social and environmental issues that can affect the survival of the company. The description indicates that agency theory is also very concerned about corporate sustainability in the context of principal - agent relationship. Agency theory also recognizes that corporate sustainability can not be achieved if the management ignores the ethical aspects and provisions of existing law. Ethics and compliance aspects of the law are two important dimensions of social responsibility and is a reflection of management awareness towards the issues of social and environmental responsibility, 
regardless of the attitude of the management is forced to run the CSR or not.

In practice, the relationship of management and the shareholders relation greatly affected the ability of management to meet the demands of the shareholder profit. The shareholders is the highest authority, but do not have enough information about the behavior of management (asymetric information) (Bonazzi \& Islam, 2007). On the other hand, in the reality of day-to-day practice, the management faces intense business competition and this condition creates difficulty for the management to fullfill its social and environmental responsibilities. The management is not willing to sacrifice the interests of profits to meet its social and the environmental responsibilities. The survey results which show the paradox attitude of the management towards its social and environmental responsibilities are evidences to this attitude. The paradox attitude is a form of responsibility to the shareholders because by fulfilling the social and environmental responsibility, the management has decrease the shareholder rights and this affects the assessment of the shareholders towards the management.

Furthermore, the shareholder support is also very influential on the extent of the management commitment in fulfilling the social and environmental responsibility (Barnea \& Rubin, 2010). The rejection of Berkshire Hathaway shareholder towards the obligation to comply with the provision of the government of the United States about the environmental (www.huftingtonpost.com, 2011) and the rejection of the Mc Donald management in the United States to conduct a survey about the negative impact of the products of McDonald (www.care2.com,2012) shows how strong the influence of motivation to achieve maximum profits in determining the management's commitment to engage in the social and the environmental issues. However, according to Barrett (2001), the greater portion of "socially responsible investors" in the shareholder composition affects the management's commitment to engage solving the social and environmental problems. Barrett (2001) states that the greater the socially responsible investor composition causes the stronger pressures for the management to get involved in solving the social and environmental problems.

Based on the description, the first proposition is: "the strength of commitment of shareholders to be involved solving the social and environmental issues affects the strength of the management commitment in implementing corporate sustainability management”.

\subsection{Humanism Paradigm and Corporate Sustainability Management}

Pirson and Lawrence (2010) and Harris and Towmey (2008) states that the world is now faced with the challenge of weight management with more frequent economic crises in many countries that are not easy to maintain the survival of the company. Pirson and Lawrence (2010) stated that in order to maintain the sustainability of the company, the management should be able to be more humanist and build transformational relationships, and developing mutually beneficial business relationship with all company's stakeholders. The survival of the company can be assured if the company is able to ensure the survival of its stakeholders, including the competitors. Strong humanist attitude will affect the attitude of management in managing social and environmental issues which are related with the company's business activities. Strong social attitudes will prevent management being two-faced, pretending and not sincere in carrying out its social responsibility. Stronger humanist attitude will encourage management strive to be good corporate activities and avoid "stupid and evil" against the 
interests of the company and the community (Banerjee, 2009). In particular, Pirson and Lawrence (2010) call this concept as Renewed Darwinian Theory (RD Theory).

The management is working for the benefit of all parties and view CSR is a tool and goal of creating wealth for all stakeholders. The main difficulty is how the implementation of RD management theory be balanced to meet the demands of the stakeholders. Humanist attitude is manifested in the form of business practices that always maximizes social responsibility and always pays attention to the law and ethics as key considerations in conducting business activities. By practising humanism, Pirson and Lawrence (2010) argue that management will be able to strengthen the company's survival.

Based on this analysis, the second propositions that can be built are: "the more intense management applying humanism paradigm, the company’s survival ability will be stronger."

\subsection{Hierarchy of Needs and Corporate Sustainability}

CSM is a strategic and dynamic issue for the management. There is no one culture that is suitable for any CSM issues being faced by the management, therefore, management is required to have the ability to build and change the organizational culture accordance with the demands of CSM issues that exist. Campbell (2009), Rice (2009) and Barrett (2001) states that a corporation is an artificial person having a certain level of requirements that are identical to the hierarchy of human needs according to Maslow (as cited in Campbell, 2009; Rice, 2009). Barrett (2001) states that the lowest requirement is to improve financial performance and employee engagement (survival). Next is the need to build quality relationships between customers, suppliers and employees (relationship), to build better business practices (self esteem), continuous product development (transformation), build unity and awareness of interdependence within the company (internal cohesion), strengthening relationships and engagement among employees (inclusion) and the highest requirement is the need to build a strong relationship of mutual dependence between internal and external stakeholders (unity) and the need to be "good citizens" (Falck \& Heblich, 2007). Furthermore, according to Rice (2009), the needs of the company can be divided into eight levels, namely (1) the need to maintain a sense of security from the threat of business risk (security), (2) the need to build relationships (connection), (3) the need to control the environment and freedom (control), (4) the need to gain the attention of the stakeholders (esteem), (5) the need to reflect personal ideas (aesthetics), (6) the need to always be assisted to learn to grow (cognitive), (7) the need for assisted reaching the target company and (8) the need to pay attention to others and practice good values are believed companies (transcendence). Furthermore, Campbell (2009) split the company in accordance with the hierarchy of needs Maslow's opinion that the physical (lowest), feeling safe, loved, recognized, and finally, self-actualization. For companies, the physical needs is the need of maintaining cash flow, thus creating the products and services according to consumer demand. Highest need is the need to consider the interests of stakeholders and act good for others. The views Campbell (2009), Rice (2009) and Barrett (2001) suggest that any company can be at the level of different needs and this affects the awareness of the management to fullfill its social and enviromental responsibilities.

Furthermore, according to Marrewijk and Werre (2003), there are six levels of the practice of 
CSM, the Pre-CS (lowest) Compliance-driven CS, Profit-driven CS, CS Caring-synergistic CS and Holistic CS (highest). Marrewijk and Werre (2003) divided the classification based on the amount of (1) the attitude of management to meet the interests of stakeholders and its self, (2) management orientation period, (3) the balance of attention to the importance of financial performance, social and environmental, and (4) management capabilities to build a harmonious and balanced relationship with all stakeholders. Pre-CS CS is the lowest level where management does not consider the interests of stakeholders, be short-term, exploitative and just financial profit oriented. Holistic CS is a CS level where management has had a stable financial performance over the long term, have a strong attitude creates a harmonious relationship with all stakeholders to support each other and always try to keep the maximum quality of the environment. The greater the power of management creates economic sustainability, the more powerful management capabilities reached the stage of Holistic CS.

Based on the theoretical description, the company that always involved cash flow problems is a company that is always looking at the problem in the short term and ignore the enviromental and social sustainability issues. This company always considers the social and environmental issues as issues that burden and tend to be dodge. Conversely, the higher the company's ability to meet its economic needs, the company will increasingly be more sensitive and proactive to social and environmental issues (Lee \& Ball, 2003). The view of Campbell (2009), Rice (2009), Marrewijk and Werre (2003), Lee and Ball (2003) and Barrett (2001) show that financial motivation is the most urgent needs. It can be used as an explanatory research findings Ameer and Othman (2012) where the average global companies are able to enjoy better financial performance by applying the concept of CSM and the ability of Starbuck in "forcing" its competitors to jointly run a program of environmental protection (Kiron et al., 2012). On the other hand, not all companies are able to enjoy better financial performance by implementing CSM. In summary, a company will have more balance financial, social and environmental awareness if the management is able to secure its long term financial performance.

Based on the description, the third propositions that can be established is: "The more powerful management capabilities to meet its long term financial performance, the management will have more concern with the issues of social and enviromental sustainability”.

\subsection{Management Capability and Corporate Sustainability}

Robinson and Boule (2012) states that there are three levels of sustainability, namely the non-sustainability, weak sustainability and strong sustainability. Non or weak sustainability is a condition in which a company does not have a high sensitivity to the issues of social life and environment and tends to be defensive (defensive) (Lee \& Ball, 2003). A company has a strong sustainability when being proactive and have a speculative commitment (Lee \& Ball, 2003; Ghobadian et al., 1998). Company with strong sustainability and speculative commitment is a company that has a strong organizational culture and always treats social and environment issues as business opportunities "opportunities seekers”. Non sustainability and weak sustainability is a company that is not able to build a strong organizational culture, looking at the social and environmental issues as a burden and does not show a real commitment to solving social and the environment issues. Based on the description, it can be concluded that 
the ability of management to build a strong organizational culture of sustainability will influence the company's sustainability (Abbett et al., 2010). Strong organizational culture is a culture in accordance with the conditions and demands of internal and external parties. In the CSM, the development of a strong organizational culture is fully depend on management capability (Caprar \& Neville, 2012; Abbett et al., 2010).

Furthermore, according to Linnenluecke and Griffiths (2010), there are four models of organizational culture groupings: (1) internal process model, (2) human resources model, (3) rational goal model and (4) open systems model. Internal process model is an organizational culture that is only oriented to economic sustainability so that, in the long run, are not able to ensure corporate sustainability. Human resources model is a model of culture that too much emphasis on the social attitudes that endanger the long-term financial performance. Rational goal model is an organizational culture that concerns with the cost efficiency and simplification of the production process therefore, this model is not able to guarantee the long term corpporate sustainability. Open system model is a model of organizational culture that emphasizes the importance of innovation to achieve environmental and social sustainability. The company's survival depends on the ability to build good relationships with the economic and social stakeholders. Therefore, management should have flexibility in running the day-to-day business activities.

To have a strong sustainability culture so as to create a strong corporate sustainability, management must have the ability to build some of the following (Robinson \& Boulle, 2012; Caprar \& Neville, 2012; Crews, D, 2011; Jorge et al., 2011; Abbett et al., 2010; Linnenluecke \& Griffiths, 2010; Grayson et al., 2008; Szekely \& Knirsch, 2005)).

- The ability to integrate the organization's vision and strategy into the implementation of CSM concept.

- The ability to ensure that all persons in organizations have embraced the truth of the vision.

- The ability to ensure that this vision has been realized in every decision, action and daily activities throughout the company's personnel.

- Ability to create a learning organization that allows for continuous improvement. Sustainability issues should be the trigger to find new and better ways and more ethical to strengthen competitiveness.

- The ability to monitor the vision, mission, values, strategies and plans are well executed.

- The ability to build an inspiring attitude and proactive leadership to become a source of inspiration and encouragement for all members of the organization.

- The ability to narrow differences in personal values and organization values.

- The ability to build a performance appraisal system and information management system that can provide accurate information about the balance of financial, social and environmental performance.

Those capability requirements shows that the strong shareholder support and management 
paradigms are not able to ensure management implements CSM well if not accompanied by the ability to apply the culture of the organization in accordance with the principles of CSM in the daily management practices. Furthermore, since the organization is a collection of people with different attitudes and motivations, the success of CSM depends on the ability of management create equality perspective, purpose, thought, word and action among all members of the organization.

Based on the description, the fourth proposition is: "The capability of management to establish and implement a sustainability culture does affect the ability of management to maintain the company's sustainability"

\subsection{Stakeholders Capability and Corporate Sustainability}

The obligation to pay attention to social and environment issues provide an extra burden on management to meet its profit responsibility. The results of empirical research shows that not all companies are able to improve the financial performance even involved in various philanthropic activities related to community empowerment and environment activities. Furthermore, sstakeholders theory states that in order to survive, a company heavily dependent on the support of stakeholders. To that end, management must be able to satisfy the different interests of different stakeholders. Management should be able to create strong collaboration with other stakeholders. Quality of collaborative relationships is crucial to ensure the corporate survival (Kiron et al., 2012; Jorge et al.,2011; Grayson et al.,2008). Quality of collaborative relationships is determined on the strength of bargaining power between the company and various stakeholders. Finally, management needs to determine who the stakeholders that have the greatest bargaining power and what the interests of these stakeholders. The result of Jamali (2008) and Papasolomou et al., (2005) research put the economic stakeholders are more important than the social stakeholders. Economic stakeholders are employees, customers, shareholders and suppliers. Social stakeholders are the community and the environment. The results showed that the economic interest is still primary motivation in determining the most important stakeholders and the main consideration in building collaboration with company's stakeholders.

Economic stakeholders remain very concerned about the economic benefits as a primary consideration in providing support to the company's survival. Research results show that consumers increasingly appreciate the philanthropic activity but consumers do not approve selling price increase if the increase is caused by the additional burden of more intense philanthropic activity (Rahim et al., 2011; Oberseder et al., 2011; Staton, 2010; Schwartz, 2008; Oppewal et al., 2006). Consumers are increasingly demanding information on corporate social responsibility, but that does not mean consumers will buy more to the company that have high philanthropic activities. In addition, research results also show that management is willing to be involved in the handling of social and environment issues as long as the suppliers can provide competitive selling price. If the company requires suppliers to supply environmentally friendly and free of social problems products, the company should bear additional cost of product because not all suppliers are able to produce such products. Therefore, a company will involve social and environmental issues of the suppliers as long as it 
creates better financial outcome for the company (Andersen \& Larsen, 2009; Maloni \& Brown, 2006; Carter, 2005).

Controversy attitude Berkshire Hathaway shareholders also indicate that the shareholders did not want their economic benefit were disrupted because the management carries out too many philanthropic activities. Government support in the form of clear legal provisions, non-discriminatory and strict law enforcement also affects the firm's ability to build collaboration. In addition, competitors also have the ability to influence the management strengths to build collaboration. An example of this is the ability of Starbucks's management to force all suppliers and competitors to participate in the development of products that are more environmentally friendly (Kiron et al.,2012). Furthermore, referring to the concept of Michael Porter (1985), the amount of competitiveness and bargaining power is determined at the level of influence of suppliers, customers, competitors and potential new competitors. Moreover, competitiveness and bargaining power is also affected by government and non-governmental organizations. This shows that the CSM success depends on the ability of management to build collaboration with economic other stakeholders. Thus, it can be concluded that the bargaining power of the company towards its stakeholders is highly dependent on the ability of management to dominate and dictate the interest of the economic stakeholders.

Based on the above discussion, the fifth proposition is: "The ability of management to build mutually beneficial collaboration with the company's economic stakeholders affects the ability of management to maintain the sustainability of the company"

\section{Conclusions and Recommendations}

\subsection{Conclusions}

The concept of CSM is an easy concept to understand, but not all companies are able to benefit CSM. Management fully understands that, at this time, carrying out the responsibilities of income is not possible to ignore the interests of the community and the environment. Social conditions and the environment can be affected and affect the interests of the company. The company is a part of the community so as to safeguard the interests of society is part of the efforts to maintain the interests of the company itself. Carry out business activity always consider the balance of the financial performance, social and environmental performances and it is believed to enhance the sustainability of a company in the long run. Nevertheless, various studies and survey results, showing not all companies are able to perform well and earn better financial performance because of the conflict of interest between stakeholders and between the of management and the stakeholders. This shows that not all companies have the same ability in running the CSM.

Various empirical research studies and surveys about the CSM management behavior suggests that to get the benefits of CSM, at least there are five conditions that must be met, namely: (1) the strength of commitment of shareholders to be involved solving the social and environmental issues, (2) the amount of levels humanist paradigm adopted by the management in day-to-day management practices, (3) the ability of management implementing philanthropic activities without worrying threat of decline in profits and reduction in 
competitiveness (higher level sustainability performance), (4) the capability of management to establish and to implement a strong sustainability culture and (5) the ability of management to build mutually beneficial collaboration between the company and the company's economic stakeholders.

\subsection{Recommendation for Further Research}

The purpose of writing this paper is to obtain propositions about the reasons for success and failure of the implementation of CSM. Based on the literature, there are at least five factors that must be considered in the implementation of the CSM. Nevertheless, the proposition in this paper can not answer all the phenomena of CSM because CSM is a complex management issues and global. These conditions led to extensive research is still needed on the practice of CSM in (1) different types of industries, (2) different types of market competition, and (3) in different countries.

\subsection{Recommendation for Corporate Management}

From the practical side, this paper provides guidance to management that embrace the concept of CSM is not enough if it is not accompanied, at least, five conditions. Therefore, before running the CSM, management needs to carry out an assessment of the conditions and requirements of internal and external parties in order to design management strategies and appropriate measures to reduce the risk of failure of the implementation of CSM.

\section{References}

Abbett, L., Coldham, A., \& Whisnant, R. (2010). Organizational Culture and The Success Sustainability Initiatives: An Empirical Analysis Using The Competing Values Framework. [Online] Available: http://www.erb.umich.edu/Research/Student-Project.htm.

Ameer, R., \& Othman,R. (2012). Sustainability Practices and Corporate Financial Performance; A Study Based on the Top Global Corporations. Journal of Business Ethics, 108, 61-79. http://dx.doi.org/10.1007/s10951-011-1063-y

Andersen, M., \& Larsen, T.S. (2009). Corporate social responsibility in global supply chains. Supply Chain Management: An International Journal, 14(2), 75-86.

Banerjee, S. B. (2009). Corporate Social Responsibility: the Good, the Bad and the Ugly. Journal of International Management, 15.118-119. http://dx.doi.org/10.1007/s

Barnea, A., \& Rubin, A. (2010). Corporate Social Responsibility as a Conflict Between $\begin{array}{llll}\text { Sahreholders. Journal of Business } & \text { Ethics, }\end{array}$ http://dx.doi.org/10.1007/s10551-010-0496-z

Barrett, R. (2001). The Seven Levels of Corporate Sustainability. Working Draft. [Online] Available: http:// www.knowinc.com

Bartlett, D. (2009). Embedding corporate responsibility: the development of a transformational model of organizational innovation. Corporate Governance, 9(4), 409-420. http://dx.doi.org/10.1108/14720700910984963 
Bonazzi, L., \& Islam, S.M.N. (2007). Agency theory and corporate governance: A study of the effectiveness of board in their monitoring of the CEO. Journal of Modelling in Management, 2(1). 7-23. http://dx.doi.org/10.1108/17465660710733022

Campbell, A. (2009). Green Business and Maslow's Hierarchy of Needs. [Online] Available:http://smallbiztrends.com/2009/04/green-business-maslows-hierarchy.html.

Care2.com. (2012). McDonalds shareholders reject health proposal. [Online] Available: http://www.care2.com/causes/mcdonalds-shareholders-reject-health-proposal.html\#ixzz2EqV gheGC.

Carter, C.R. (2005). Purchasing Social Responsibility and Tim Performance. The Key Mediating Roles of Organizational Learning and Supplier Performance. International Journal of Physical Distribution \& Logistics Management, 35(3), 177-194.

Caprar, D.V., \& Neville,B.A., (2012). ”Norming” and “Conforming“: Integrating Cultural and Institutional Explanations for Sustainability Adoption in Business. Journal of Business Ethics, 110, 231-245. http://dx.doi.org/10.1007/s10551-012-1424-1

Carroll, A.B. (1991). The Pyramid of Corporate Social Responsibility: Toward the Moral Management of Organizational Stakeholders. Business Horizons. July - August. http://dx.doi.org/10.1016/0007-6813(91)90005-G

Clemens, B., \& Bakstran, L. (2010). A framework of theoretical lenses and strategic purposes to describe relationship among firm environmental strategy, financial performance and environmental performance. Management Research Review, 33(4), 393-405. http://dx.doi.org/10.1108/01409171011030480

Cordasco, P. (2012). Consumers Continue to Prioritize Social Responsibility Across Business Sectors, Despite Recession. [Online] Available: http://www.burson-marsteller.com/newsroom/lists/Press Releases.

Crews, D.R. (2010). Leadership and Sustainability: Strategies for Implementiing Sustainability: Five Leadership Challenges. SAM Advanced Management Journal. Spring. 75.

Crook, C. (2005). The good company. The Economist. 20 January.

Falck, O., \& Heblich, S. (2007). Corporate Social responsibility Doing Well by Doing Good. Business Horizons, 50, 247-254. http://dx.doi.org/10.1016/j.bushor.2006.12.002

Ghobadian, A., Viney,H., Liu, J., \& James, P. (1998). Extending Linear Approaches to Mapping Corporate Environmental Behaviour. Business Strategy and the Enviroment, II(6), 343-359.http://dx.doi.org/10.1002/(SICI)1099-0836(199802)7:1<13::AID-BSE133>3.0.CO;2 $-\mathrm{D}$

Gioia, D. (1999). Response practicability, paradigms, and problems in stakeholders theorizing. Academy of Management Review, 24(2), 228-232. http://dx.doi.org/10.2307/259077

Grayson, D..M.,L., Slaughter,S., Rodriguez,M.A., Jin,Z., \& Tay,S. (2008). A New Mindset for Corporate Sustainability. BT and Cisco 
Gupta, M. (2012). Corporate Social Responsibility in the Apparel Industry. An Exploration of Indian Consumer's Perceptions and Expectations. Journal of Fashion Marketing and Management, 16(2), 216-233

Harris, D.L., \& Towmey, D.F. (2008). Corporation Perspective vs Enterprise Perspective: Issues of Competitiveness and Sustainability. Competition Forum, 6, 75-80.

Huftingtonpost. (2011). Berkshire shareholders reject emissions goals. [Online] Available: www.huftingtonpost.com.2011. Berkshire shareholders reject emissions goals.

Jamali, D. (2008). A Stakeholder Approach to Corporate Social Responsibility: A Fresh Perspective into Theory and Practice. Journal of Business Ethics, 82, 213-231. http://dx.doi.org/10.1007/s10551-007-9572-4

Jones, B., Bowd, R., \& Tench, R. (2009). Corporate irresponsibility and corporate social responsibility:competing realities. Social Responsibility Journal, 5(3), 300-310. http://dx.doi.org/10.1108/17471110910977249

Jorge, A., Castello, I., de Colle,S., Lenssen,G., Neuman, K., \& Zollo, M. (2011). Introduction to the Special Issue Integrating Sustainability in Business Models. Journal of Management Development, 30(10),941-964.

Kiron, D., Kruschwit, N., Haanaes, K., \& Velken, I.S. (2012). Sustainability Nears a Tipping Point. MIT Sloan Management Review. Winter. 53. 2.

Kolstad, I. (2007). Why Firms Should Not Always Maximize Profits. Journal of Business Ethics, 76, 137-145. http://dx.doi.org/10.1007/s10551-006-9262-7

Laan, G.V, Hans Van Ees, \& Arjen Van Wiitteloostuijn. (2008).Corporate Social and Financial performance: An Extended Stakeholder Theory, and Empirical Test with Accounting Measures. Journal of Business Ethics, 79, 299-310. http://dx.doi.org/10.1007/s10551-007-9398-0

Lanoizelee, F.Q. (2011). Are competition and corporate social responsibility compatible?.Society and Business Review, 6(1).

Laszlo, C., \& Zhexembayeva, N. (2011). Embedded Sustainability, The Next Big Competitives Advantage. Stanford, California: Stanford Business Books.

Lee, D.D., R.W.Faff, R.W., \& Smith, K.L. (2009). Revisiting the Vexing Question: Does Superior Corporate Social Performance Lead to Improve Financial Performance?. Australian Journal of Management, 34, 1-49. http://dx.doi.org/10.1177/031289620903400103

Lee, K.H., \& Ball, R. (2003). Achieving Sustainable Corporate Competitiveness: Strategic Link between Top Management's (Green) Commitment and Corporate Environmental Strategy. [Online] Available: http://www.greenleaf-publishing.com/productdetail.kmd?productid=476.

Linnenluecke, M.K., \& Griffiths, A. (2010). Corporate sustainability and organizational culture. Journal of World Business, 45, 357-366. http://dx.doi.org/10.1016/j.jwb.2009.08.006 
Maloni, M.J., \& Brown, M.E. (2006). Corporate Social Responsibility in the Supply Chain: An Application in the Food Industry. Journal of Business Ethics, 68, 35-52. http://dx.doi.org/10.1007/s10551-006-9038-0

Marrewijk, M., \& Werre, M. (2003). Multiple Levels of Corporate Sustainability. Journal of Business Ethics, 44, 107-119.

Maslow, A.H. (1968). Towards a Psychology of Being. (2 ${ }^{\text {nd }}$ ed.). New York: Van Nostrand Reinhold. http://dx.doi.org/10.1037/10793-000

Maslow, A.H. (1987).Motivation and Personality. ( $3^{\text {rd }}$ ed.). New York: Harper and Row Publishers Inc.

Menguc, B., Auh, S., \& Ozanne, L. (2010). The Interactive Effect of Internal and External Factors on a Proactive Environmental Strategy and its Influence on a Firm's Performance. Journal of Business Ethics, 94, 279-298. http://dx.doi.org/10.1007/s10551-009-0264-0

Mittal, R.K., N.Sinha, N., \& A.Singh, A. (2008). An analysis of linkage between economic value added and corporate social responsibility. Management Decisions, 46(9), 1437-1443. http://dx.doi.org/10.1108/00251740810912037

Oberseder, M., Schegelmilch, B.B., \& Gruber, V. (2011). Why Don’t Consumers care about CSR? - A Qualitative Study Exploring the Role of CSR in Concsumption Decisions. Empirical $\begin{array}{llll}\text { Paper. Journal of Business } & \text { Ethics. }\end{array}$ http://dx.doi.org/10.1007/s10551-011-0925-7

Oppewal, H., Alexander, A., \& Sullivan, P. (2006). Consumer perception of corporate social responsibility in town shopping centres and their influence on shopping evaluation. Journal of $\begin{array}{llll}\text { Retailing and Consumer } \quad \text { Services, } & \text { 13, }\end{array}$ http://dx.doi.org/10.1016/j.jretconser.2005.08.015

Osthus, J. (2011). Corporate Social Responsibility and Customer Loyalty. [Online] Available: http://www.reputationforward.com/2011/05/corporate-social-responsibility.

Papasolomou, I.D, Kapardis, K., \& Katsilioudes, M. (2005). Corporate Social Responsibility: The Way Forward? Maybe Not!. European Business Review, 17(3), 263-279. http://dx.doi.org/10.1108/09555340510596661

Peters, R., \& Mullen, M.R. (2009). Some Evidence of the Cummulative Effects of Corporate Social Responsibility on Financial Performance. Journal of Global Business Issues, 3, 1-14.

Pirson, M.A \&Lawrence, P.R. (2010). Humanism in Business - Towards a Paradigm Shift?. Journal of Business Ethics, 93, 553-565. http://dx.doi.org/10.1007/s10551-009-0239-1

Porter, M.A. (1985). Competitive Advantage. New York: Free Press.

Rahim, R.A., F.W.Jalaludin, F.W., \& Tajuddin, K. (2011). Consumers Behaviour Towards CSR in Malaysia. Asian Academy of Management Journal, 16(1), 119-139. 
Raynor, M.E. (2009). End shareholder value tranny: put the corporation first. Strategy and Leadership, 37, 4-11. http://dx.doi.org/10.1108/10878570910926007

Rice, J. (2009). Maslow and corporate responsibility. [Online] Available: http://www.fruitfulstrategy.com/blog/2009/04/maslow-and-corporate-responsibility.

Robins, F. (2008). Why corporate social responsibility should be popularized but not imposed. Corporate Governance, 8(3), 330-341.

Robinson, D., \& Boulle, M. (2012). Overcoming Organizational Impediments to Strong Sustainability Management. The Business Review, Cambridg, 20(1).

Schwartz, P. (2008). Why Customers May Never Care About Your Corporate Social Responsibility. [Online] Available: www.care2.com.

Staton, L. (2010a). Corporate Social responsibility (CSR) - Do customers really care?. [Online] Available:

http://www.reputationforward.com/2010/09/corporate-social-responsibility-csr-do-customersreally-care.html.

Staton, L. (2010b). Business Leaders Continue to Find Value in Sustainability. [Online] Available:

http://www.reputationformward.com/2010/12/business-leaders-continue-to-find-value-in-sust ainability.html.

Staton, L. (2011). How CEOs See the Future of Sustainability. [Online] Available: http://www.reputationforward.com/2011/06/how-CEOs-see-the-future-of-sustainability.html.

Szekely, F., \& Knirsch, M. (2005). Responsible Leadership and Corporate Social Responsibility: Metrics for Sustainable Performance. European Management Journal, 23(6), 628-647.

Verschoor, C.C. (2003). More evidence of better financial performance. Strategic Finance. Nov. 18-20.

Verschoor, C.C. (2008). Citizenship Survey Shows Gaps Between Rhetoric and Reality. Strategic Finance, 89, 3-14.

\section{Copyright Disclaimer}

Copyright reserved by the author(s).

This article is an open-access article distributed under the terms and conditions of the Creative Commons Attribution license (http://creativecommons.org/licenses/by/3.0/). 